\title{
Prevalence of Gastrointestinal Parasites on Beef Cattle in Jombang District
}

\author{
${ }^{1)}$ Melda Mufidatul Ifqiyyah, ${ }^{2)}$ Boedi Setiawan ${ }^{(3)}$ Agus Wijaya \\ ${ }^{1)}$ Student, Faculty of Veterinary Medicine, Universitas Airlangga, melda.mufidatul-12@fkh.unair.ac.id \\ ${ }^{2}$ Division of Basic Veterinary Medicine, Faculty of Veterinary Medicine, Universitas Airlangga \\ 3) Veterinary Internal Medicine Division, Department of Clinic, Reproduction and Pathology, Faculty \\ of Veterinary Medicine, IPB University \\ Received: 15-08-2021, Accepted: 25-o8-2021, Published Online: 30-09-2o21 \\ Corresponding author: boedi-s@fkh.unair.ac.id
}

\begin{abstract}
The disease that is quite detrimental to cattle is gastrointestinal parasitic infection. Gastrointestinal parasites infect the cattle by taking host nutrients that would caused emaciation, lethargy, and decreased productivity. This study aims to determine the prevalence of gastrointestinal parasites in cattle in Jombang District. This research was conducted in July to August 2019 with 100 samples of cattle feces. Sample examinations were carried out in the laboratory of the Division of Veterinary Parasitology, Universitas Airlangga using the sedimentation and floating methods. Detection of parasites in all samples using microscope with magnification of 10ox and 40ox. On examination, several types of parasites were found included Strongyloides papillosus, Toxocara vitulorum, Oesophagostomum spp., Moniezia expansa, Blastocystis spp. and Eimeria spp. The results of this study were found the prevalence of gastrointestinal parasites on beef cattle in Jombang district was $35 \%$ with a worm infection prevalence of $15 \%$ and protozoan infections of $20 \%$.
\end{abstract}

Keywords : Jombang District, prevalence, gastrointestinal parasite, beef cattle.

\section{Introduction}

Beef cattle are superior products in the livestock sector in Indonesia. The amount of beef consumed in Indonesia in 2014 was 438,770 tons and beef imports in the same year reached 246,609 tons (Pusdatin, 2015). Lack of attention to a good cattle rearing system causes the emergence of various kinds of disease seeds caused by parasites. In addition to causing health problems in cattle, parasitic infections can also cause economic losses for the farmers. If livestock are infected, it results in hampered body development, so that the carcass or meat produced is of poor quality and the breeder has to bear considerable costs (Ngurah and Widnyana, 2013). This parasite consists of a number of groups of worms from the class nematodes, cestodes, and trematodes as well as protozoa such as Coccidia. Gastrointestinal parasites infect the digestive tract resulting in a decrease in nutrient absorption, and cause growth delays so that the quality of cattle decreases (Astiti et al., 2011). Parasitic infection will cause growth delay, especially in young cattle (Nofyan et al., 2010). Zajac and Conboy (2012) reported that protozoan infections can cause diarrhea. The presence of oxygen, temperature, humidity, and lack of direct contact with ultraviolet (UV) radiation, supports oocyst survival and sporulation (Purwanta et al., 2009). Tolistiawaty et al. (2016) reported that cows in TPH Sigi District were infected with worms as much as $63.91 \%$ and protozoa as much as $3.09 \%$. Paramitha et al. (2017) reported the prevalence rate of helminthiasis in Bali province is $38.22 \%$. Cases of gastrointestinal protozoa infection in beef cattle, Kertawirawan (2014) reported the prevalence rate of Eimeria sp. in Musi Village, Gerokgak Sub-District, Buleleng District for calves/branches of $82.61 \%$ and $65.52 \%$ in broodstock. Indraswari et al. (2017) reported that in Nusa Penida it was $12 \%$ with two types of protozoa, namely Eimeria auburnensis and Eimeria bovis. Jombang District has a beef cattle population of 66,980 heads. Among the Sub-Districts in Jombang District, Plandaan Sub-District has the most beef cattle population, namely 8,507 heads (BPS, 2018). Information on the prevalence of beef cattle gastrointestinal parasites on smallholder farms in Jombang District is not yet known. This study was conducted to obtain basic data on the types of parasites and the prevalence of gastrointestinal parasites in beef cattle in Jombang District. 


\section{Materials dan Methods}

This research is a descriptive study with a cross-sectional study design. Samples were declared positive if helminths and protozoa were found by one or more methods on stool examination. In this study, the sample observed was beef cattle feces. The cow feces obtained were examined by sedimentation and floating methods to determine gastrointestinal parasites in the examination. From all positive samples, the prevalence rate was calculated.

This study begins with data collection of cattle in Jombang District, which includes race/nation, sex, age and number of cows. In this study, samples of beef cattle were taken as a whole that were more than two years old and were female, because most of the breeders kept cows as sires. After collecting data, the next step is to calculate the sample size from the population using the Slovin formula and the sampling technique is random sampling. The fecal samples obtained were examined by sedimentation method and floating method to determine the presence of gastrointestinal parasitic infection in the cow.

The population of this research is beef cattle kept by residents in Jombang District as many as 66,980 heads. The cow population is almost entirely female, with an average age of more than 2 (two) years because generally cows kept by farmers are used as broodstock. There are various formulas that can be used to calculate the sample size required in the study. In this study, the method of determining the sample size was the Slovin formula (Sugiyono, 2006): $\{\mathrm{n}=\mathrm{N} / 1+\mathrm{Ne} 2\} ; \mathrm{n}=$ sample, $\mathrm{N}=$ population, $\mathrm{e}=$ error tolerance limit value of $10 \%$ or o.1. The calculation of the sample size is based on an error tolerance of $10 \%$ so as to obtain $90 \%$ confidence in the population, then the sample size is $99.8 / 100$ individuals.

In this study, samples were taken from fresh beef feces shortly after defecation and taken randomly from the beef cattle population in five Sub-Districts in Jombang District, namely Kudu Sub-District, Plandaan Sub-District, Ngusikan Sub-District, Jogoroto Sub-District and Mojoagung Sub-District. Sufficient stool samples were taken, approximately 5-10 grams with the addition of $2 \% \mathrm{~K}_{2} \mathrm{Cr}_{2} \mathrm{O}_{7}$ for protozoa fertilizing agents and $10 \%$ formalin for worm egg preservatives and then put in a plastic clip bag. Each plastic is labeled with the identity of each cow, sub-district and preservation. The samples were taken to the laboratory for examination (Mumpuni et al., 2007). The collected samples were examined at the Laboratory of the Division of Parasitology, Faculty of Veterinary Medicine, Airlangga University, Surabaya. The results of the examination were declared positive if one of these methods found gastrointestinal parasites, namely worm eggs and protozoan cysts or oocysts (Mumpuni et al., 2007).

The prevalence rate of parasites in beef cattle in Jombang District was calculated based on Timreck (2004) using the following prevalence formula: Prevalence $=$ (number of positive samples/number of all observed samples) $\mathrm{x} 100 \%$. The data obtained were analyzed descriptively and presented in tabular form. Identification of parasitic worm eggs and protozoan cysts or oocysts is based on morphology according to manuals and identification books (Pusarawati et al., 2013).

\section{Results and Discussion}

The results of a study conducted from June to August 2019 on 100 samples of cow feces taken in Jombang District obtained 35 positive samples, indicating the prevalence of gastrointestinal parasites in beef cattle was 35\%. Gastrointestinal parasites found in Jombang District consisted of Strongyloides papillosus with a prevalence rate of $5 \%$, Oesophagostomum spp. by $1 \%$, Toxocara vitulorum with a rate of $7 \%$, Moniezia expansa with a prevalence rate of $2 \%$, Blastocystis spp. by $5 \%$ and Eimeria spp. with the highest prevalence rate of $15 \%$. The total percentage of the prevalence of gastrointestinal parasites through examination of feces that infect beef cattle in Jombang District can be seen in Table 1.

Based on the results of a study of 100 samples of cow feces taken in Jombang District, 35 positive samples were obtained, indicating the prevalence of gastrointestinal parasites through stool examination was $35 \%$. Sampling for this study was carried out in June which is included in the dry season, so that the environmental conditions were dry, not humid and not muddy. It is natural that very few gastrointestinal parasitic infections are found in beef cattle in Jombang District. Conditions suitable for the growth of various types of parasites are humid areas to continue their life cycle (Purwantan et al., 2006). The prevalence rate of infection from worm eggs is $15 \%$. This is different from the research conducted by Paramitha et al. (2017) who reported the prevalence rate of gastrointestinal helminthiasis in beef cattle at LPA Benowo Surabaya of $73 \%$. 
The high prevalence rate is probably due to the cattle kept in LPA Benowo-Surabaya being grazed simultaneously with cows and other livestock, where all livestock carry out all activities such as defecation and feeding in one place so that the possibility of transmitting parasites from cows to cows is very large. Environmental conditions in the LPA are also very dirty and polluted. Contaminated feed and inadequate environmental sanitation can be a source of worm transmission in cattle (Levine, 1990). Meanwhile, the prevalence rate of worm infection in beef cattle in Jombang District is lower due to better cage maintenance and management systems. Beef cattle are housed in a concrete-floored cage with a drain for feces and urine. Cows are fed green grass such as sugarcane shoots and sometimes fed soybean dregs or cake. This is in accordance with Andrade et al. (2001) that helminth infections can be affected by poor sanitation and environmental conditions.

Table 1. Prevalence of Gastrointestinal Parasites in Beef Cattle in Jombang District

\begin{tabular}{lcc}
\hline \multicolumn{1}{c}{ Kind of Parasites } & Positive & $\%$ \\
\hline Strongyloides papillosus & 5 & $5 \%$ \\
Oesophagostomum spp. & $\mathbf{1}$ & $\mathbf{1 \%}$ \\
Toxocara vitulorum & 7 & $7 \%$ \\
Moniezia expansa & $\mathbf{2}$ & $\mathbf{2} \%$ \\
Blastocystis spp. & 5 & $5 \%$ \\
Eimeria spp. & $\mathbf{1 5}$ & $\mathbf{1 5 \%}$ \\
\hline Number of Positive Samples & 35 & $35 \%$
\end{tabular}

Protozoal infection by $20 \%$. This is also different from the results of research conducted by Saputri et al. (2018) in Bali cattle in Mengwi Sub-District, protozoa infection was $35.23 \%$. The difference in prevalence that occurs can be influenced by environmental factors. Environmental factors that influence the prevalence of gastrointestinal protozoal infections include climate change, environmental temperature, humidity, altitude of an area, rainfall, soil conditions (Putignani and Menichella, 2010; Giarratana et al., 2012; Kantzoura et al., 2012). Other factors that can affect the prevalence of gastrointestinal protozoan infections in beef cattle are animal age, sex, physiological conditions and animal immunity, contamination by parasites, maintenance management including treatment and maintenance systems, sanitation, population density, geographical distribution and regional conditions (Apsari et al., 2016).
Based on the results of the examination, it was found that the types of gastrointestinal parasites in beef cattle belonging to the Nematoda class included Strongyloides papillosus, Toxocara vitulorum and Oesophagostomum spp. The type of worm eggs from the Trematoda class was not found. Types of worm eggs from the class Cestoda found eggs of Moniezia expansa. The type of protozoa found Blastocystis spp. and Eimeria spp.. Determination of the type of parasite is based on morphology and according to manuals and identification books (Pusarawati et al., 2013). In this study, the size of the worm eggs from Moniezia expansa was triangular and contained pyriform aparantus. This is in accordance with what Subekti et al. (2010) that the eggs of Moniezia expansa are triangular in shape with a size of 56-57 $\mathrm{m}$ and have a pyriform apparatus.

Toxocara vitulorum eggs are round with thick walls. This is in accordance with what was reported by Yuda (2014) that the eggs of the Toxocara vitulorum measuring $70 \mathrm{x} 80 \mathrm{~m}$ are slightly round, yellowish in color and have thick walls. The wall serves as a defense for worm eggs so that they can survive for a long time in the environment until they are eaten by the host.

Eggs of Oesophagostomum spp. with ovalshaped, it has a thin membrane and contains 816 cells. Strongyloides papillosus worm eggs with characteristic thin walls and inside already contain worm larvae. This is in accordance with what was reported by Subekti et al. (2010) that the eggs of Oesophagustomum spp. have a thin layer or membrane. Elliptical egg shape. The egg contains 8-16 cells and measures 73-89 x 34-45 $\mathrm{m}$. Strongyloides papillosus has an egg size of $4 \mathrm{O}^{-}$ $60 \times 20-26 \mathrm{~m}$, when it is released it contains larvae with thin egg walls.

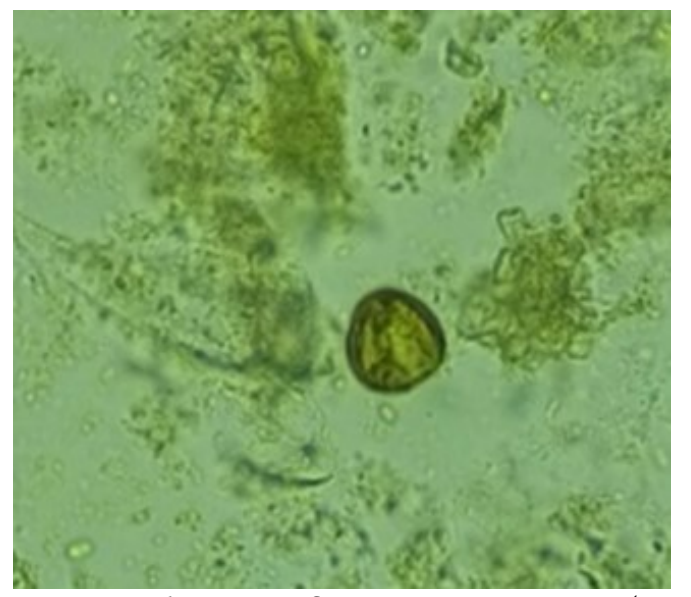

Figure 1. The egg of Moniezia expansa (100x magnification) 


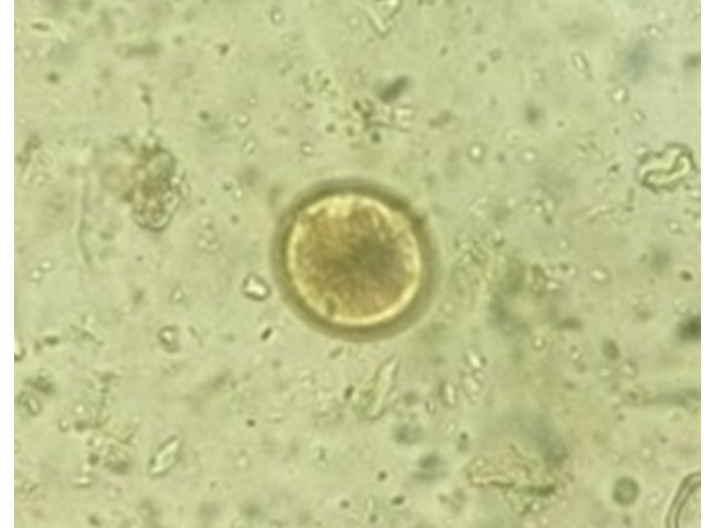

Figure 2. The egg of Toxocara vitullorum (100x magnification)
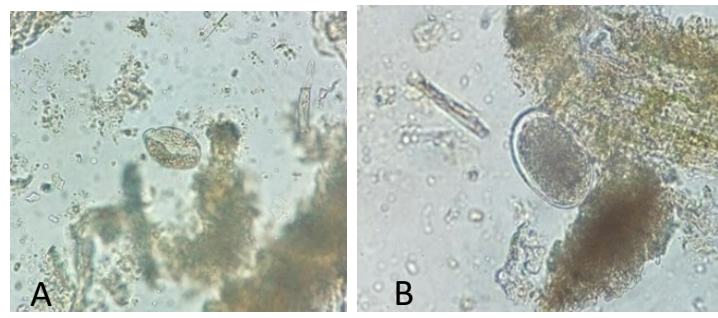

Figure 3. The egg of Strongyloides papillosus (A) and The egg of Oesophagostomum spp. (B) (10ox magnification)

In this study also found Eimeria spp. round and oval in shape. This is in accordance with what is explained by Doviansyah (2015) that the most common oocyst shape is round. Oocysts have a transparent wall that serves to protect the survival of oocysts in nature. Some species have a small pore that opens at one end of the oocyst called a microphile (cap). Oocysts can be divided into 2 types, namely oocysts that have not sporulated and oocysts that have sporulated. Oocysts that have not sporulated have a single cell, the sporon. The sporulated oocyst has four sporocysts, each containing two sporozoites.

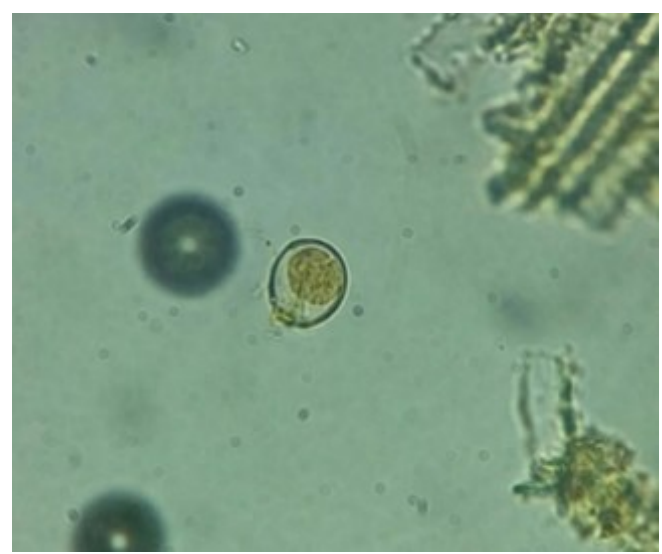

Figure 4. Eimeria spp. Oocyst (40ox magnification)
Cyst Blastocystis spp. transparent round and in the middle there is a vacuole. This is in accordance with what was stated by Prasetyo (2005) that Blastocystis spp. round or oval, transparent, located in the middle, often referred to as the central body is a vacuole of Blastocystis spp., so the stage is called the central body stage or vacuolar stage.

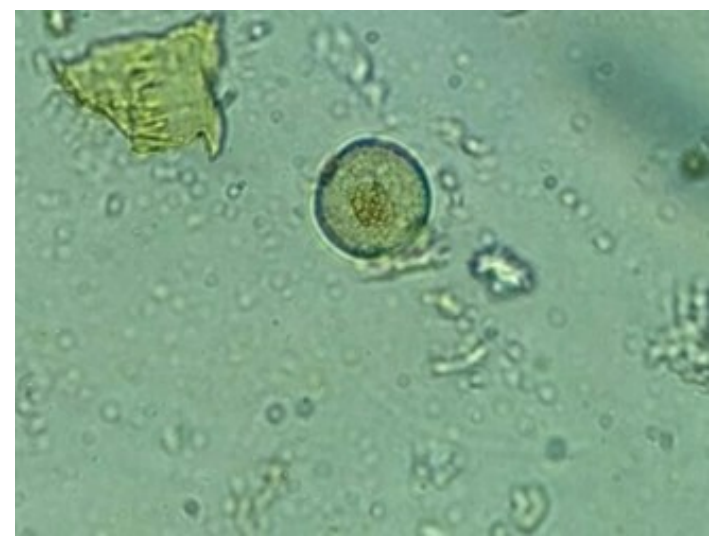

Figure 5. Cyst of Blastocystis spp. (40ox magnification)

\section{Conclusions}

Based on result of this study can be concluded that the prevalence of gastrointestinal parasitic infections in beef cattle in Jombang District was $35 \%$, with the prevalence of helminth infections $15 \%$ and protozoa infections $20 \%$. The types of gastrointestinal parasites found in the examination of beef cattle feces samples in Jombang District were from the Nematode class, namely Strongyloides papillosus, Toxocara vitulorum and Oesophagostomum spp. Types of worm eggs from the class Cestoda found eggs of Moniezia expansa. The type of protozoa found Blastocystis spp. and Eimeria spp. Several recommendations were beef cattle that are kept in cages should be cleaned regularly of feces and urine and the feed given to cows needs to be maintained so as not to allow other parasites to infect beef cattle. Cage cleaning can be done every day at least once a day. Forage collection should not be done too early or late, because the possibility of contamination of eggs and worm larvae in forage feed is higher. The deworming program is carried out regularly to prevent cases of gastrointestinal worm infections.

\section{References}

Astiti, L.G., T. Panjaitan dan Wirajaswadi. 2011. Uji Efektivitas Preparat Anthelmintik pada Sapi bali di Lombok Tengah. Pengkajian 
dan Pengembangan Teknologi Pertanian. 14(2) : 77-83.

Badan Pusat Statistika. 2018. Kabupaten Jombang dalam Angka 2018. Jombang (ID): BPS.

Indraswari, A.A.S., N.K. Suwiti, I.A.P. Apsari. 2017. Protozoa gastrointestinal: Eimeria auburnensis dan Eimeria bovis menginfeksi sapi bali betina di nusa penida. Buletin Veteriner Udayana 9(1): 112-116.

Kertawirawan, I.P.A. 2014. Identifikasi Kasus Penyakit Gastrointestinal Sapi Bali dengan Pola Budidaya Tradisional pada Agroekosistem Lahan Kering Desa Musi Kecamatan Gerokgak Kabupaten Buleleng. Buletin Teknologi dan Informasi Pertanian. 12(36): 73-80.

Koesdarto, S., S. Subekti., S. Mumpuni., H. Puspitawati dan Kusnoto. 2007a. Buku Ajar Ilmu Penyakit Nematoda Veteriner. Departemen Parasitologi Fakultas Kedokteran Hewan Universitas Airlangga. Surabaya.

Levine, ND. 1985. Protozoologi Veteriner. Soekardono S, penerjemah; Brotowidjojo MD, editor. Yogyakarta (ID): Gadjah Mada University Press.

Levine, N.D. 1990. Buku Pelajaran Parasitologi Veteriner. Gadjah Mada University Press. Yogyakarta. 124-288; 383-396.

Mumpuni, S., S. Subekti, s. Koesdarto, H. Puspitawati, Kusnoto. 2007. Penuntun Praktikum Ilmu Penyakit Helminth Veteriner. Fakultas Kedokteran Universitas Airlangga. Surabaya.

Ngurah, I.G. dan P. Widnyana. 2013. Prevalensi infeksi parasit cacing pada saluran pencernaan sapi bali dan sapi rambon di desa wosu kecamatan bungku barat kabupaten morowali. Agropet. 10:39-46.

Nofyan, E., K. Mustaka, R. Indah. 2010. Identitas Jenis Telur Cacing Parasit Usus Pada Ternak Sapi (Bos sp) dan Kerbau (Bubalus sp) Di Rumah Potong Hewan Palembang. Jurnal Penelitian Sains, 10:06-11.

Paramitha, R.P., R. Ernawati, S. Koesdarto. 2017. Prevalensi Helminthiasis Saluran Pencernaan melalui Pemeriksaan Feses pada Sapi di Lokasi Pembuangan Akhir (LPA) Kecamatan Benowo Surabaya. J. Parasite Sci.1(1).
Purwanta, Nuraeni, J.D. Hutauruk, S. Setiawaty. 2009. Identifikasi Cacing Saluran Pencernaan (Gastrointestinal) Pada Sapi Bali Melalui Pemeriksaan Tinja di Kabupaten Gowa. Jurnal Agrisistem. 5(1): 10-21.

Pusarawati, S., B. Ideham, Kusmartisnawati, Tantular, S. Indah, Basuki dan Sukmawati. 2013. Atlas Parasitologi Kedokteran. Jakarta : EGC.

Pusat Data dan Informasi Sekretariat Jendral Kementrian Pertanian. 2015. Outlook Komoditas Pertanian Subsektor Peternakan Daging Sapi. Jakarta (ID): Pusat Data dan Informasi Sekretariat Jendral Kementrian Pertanian.

Soulsby, E.J.L. 1986. Helminths, Arthropods and Protozoa of Domesticated Animals. The English Language Book Society. Baillaire Tindall. London.

Subekti, S., S. Koesdarto, S. Mumpuni, H. Puspitawati dan Kusnoto. 2007. Penuntun Praktikum Ilmu Penyakit Helminth Veteriner. Departemen Pendidikan Nasional. Fakultas Kedokteran Hewan Universitas Airlangga. Surabaya.

Sugiyono. 2006. Metode Penelitian Kuantitatif Kualitatif dan R\&D. Bandung(ID): Alfabeta.

Timreck, T.C. 2004. Epidemiologi Suatu Pengantar edisi 2, penerjemah: Munaya Fauziah, Apriningsih, Palupi Widyastuti, Mulia Sugiarti, Ratnawati, editor EGC. Jakarta.

Tolistiawaty, I., J. Widjaja, L.T. Lobo dan R. Isnawati. 2016. Parasit Gastrointestinal Pada Hewan Ternak Di Tempat Pemotongan Hewan Kabupaten Sigi, Sulawesi Tengah. Balai Litbang P2B2. 12(2) : 71-78.

Wegayehu, T., H. Adamu, B. Petros. 2013. Prevalence of Giardia duodenalis and Cryptosporodium species infection among children and cattle in North Shewa Zone, Ethiopia. BioMed Central Infectious Disease 13(417): 1-7.

Williamson, G. and W.J.A. Payne. 1993. Pengantar Peternakan di Daerah Tropis (An Introduction Animal Husbandry in the Tropic). 5th Ed. Gadjah Mada University Press. Yogyakarta. 1-6o. 
Wisesa, I.B.G.R., F.M. Siswanto, T.A. Putra, I.B.M. Oka, N.A. Suratma. 2015. Prevalence of Balantidium sp. in bali cattle at different areas of Bali. International Journal of Agriculture Forestry and Plantation 1(Sept): 49-53.

Zajac, A.M., A.C. Gary. 2012. Veterinary Clinical Parasitology. 8th ed. John Wiley \& Sons, Inc. UK. 